\title{
Is the Past in Another Country? A Case Study of Rural-Urban Affinity on Mudik Lebaran in Middle Java ${ }^{1}$
}

\author{
Vissia I. Yulianto \\ Dept. of Social and Cultural Anthropology \\ Albert-Ludwigs University, Freiburg im Breisgau
}

\section{Introduction}

Each year millions of Indonesians return to their anchestors and family homes to celebrate Lebaran, the end of Muslim fasthing month. Not only Muslims, but all Indonesians have adopted this as an annual ritual of reconnecting, remembering and recharging. This mass home coming is known as mudik Lebaran. Typically, it involves travel from centers of employment or education - cities - to rural villages or provincial towns where the aspiring offspring had left behind family to set out to make a life for themselves. The ritual typically manifests it self in traffic chaos: buses, trains, motorbikes, ships and planes groan under the weight of the returnees, each carrying presents for loved and revered ones that prove how much they have been missed and how much they have been valued. It also proves how successful the givers have been which helps to justify the absences.

The significance of mudik points to how important the ties with the village, region or province of origin continous to be but also clearly demonstrates that the rural-urban difference remains an important fault-

\footnotetext{
$<?>$ This research was conducted in paralell with my $\mathrm{PhD}$ research project entititled "Reframing Modernity in Contemporary Indonesia: An Ethnographic Study on Ideas of 'Center' and 'Periphery' on Java and Sulawesi”. The research has been supported by the German Federal Ministry of Education and Research under the grant no. 01UC0906. The expressed views in this paper are certainly personal and must not be attibuted to the German Federal Ministry of Education and Research.
} 
line 'dividing' contemporary Indonesian society. The concern of this study is not to discuss the dichotomy between the two but to explore the association between the urban and rural in term of its social as much as its cultural significance. By paying attention to the social and cultural aspect, the paper will demonstrate how Indonesian people effectively engage in their rural and urban lives. In this context, the paper seeks to make a contribution to studies of regional migration as well as rural-urban interaction which has not been widely explored academically so far. ${ }^{2}$

David Lowenthal (1985:44) has pointed out that the relationship between the past and present rests on the fact that the past has been the source of familiarity, guidance, identity, enrichment and escape. The central idea of this present paper is to suggest that this 'familiar past' is important to contemporary urbanised Middle Javanese who during the Lebaran holiday call on their ancestral roots to retain a degree of autonomy against modernity or to return to their 'disappearing past' as 'tourists'. These two objectives aim at separate and apparently contradictory directions: the former seeks to find an authentic past as a source of maternal nourishment; the later exploits the past as consumption to transform the past into a 'different country'. In this context, past is clearly not limited to the geography of its physical setting of teritory or place but it refers more to a sense of cultural entity, life style and identity.

This study of the association between the urban and the rural in term of its social as much as cultural significance of urban returnees during Lebaran season in Middle Java is a report on an etnographic study emphasising a participant observation approach. The ethnography is situated in two villages in Middle Java, Tegaldowo and Gandurejo in the Gemolong sub-district. Field work was conducted between August to September 2010 during the Lebaran season.

2 Some studies (Lu Y, 2010; Rukmana, 2007; Sumarwoto, 2002 and Firman, 2000; Dileeman, 2011) have suggested that the rural-urban relationship is a fundamental issue in Indonesia. Firman for example, points out that cultural dualism pervades Indonesian urban society (Firman, 2000) and Dieleman (2011) addresses rural-urban issues through the lens of new town development. 
I should be very clear here to mention that the fieldwork undertaken during the August-September 2010 Lebaran season was essentially a 'home anthropology'. However, in regard to data gathering, there is often a question about the relative objectivity of an insider researcher who study his or her own society which may lead to an enquiry of taking values and attitudes of the society for granted. But in fact, doing anthropology at home is noteworthty (Jackson 1987:8-11) as it provides a perspective from the inside. I argue that in relation to this study, the fact that I am a member of the society I am familiar with the day to day life and the social context of the people of concern in my research sites, and having an understanding of the unwritten emotional and cultural significance of the process under investigation, enables me to both identify and examine a unique aspect of Javanese life. Hence, the danger of taking things for granted is something I should be aware of. This article opens by describing peculiaritis of Lebaran celebration in Indonesia. It then goes on the presentation of empirical data and conclusion with analysis of research findings.

\section{Pecularities of Indonesian Lebaran}

Similar to the American tradition of Thanks Giving and of Christmas in the 'West' or Imlek, the celebration of the Chinese New Year, when people evince a 'return to family' ethos, Mudik Lebaran is the annual home coming for the majority of Indonesians. There are at least two peculiarities which make Mudik Lebaran in Indonesia different from the other 'returning family' traditions mentioned above. The first is that for both Muslim and non-Muslim minorities in Indonesia the celebration of Lebaran is the occasion for everybody for asking forgiveness (maaf lahir batin): children of their elders, neighbours of neighbours, and this day, business people of their customers. This 'forgiving tradition' is a mixture between Islamic values (Sairin 2005:193), Javanese and other regional local customs that has become an Indonesian national tradition. Although Lebaran is usually associated with Muslim celebration, nonMuslim believers in Indonesia are also fully engaged with this tradition. 
Central to its longevity, then research suggest that the key motivation of those Lebaran returnees is to reunite with their parents and families and to revitalize the family connection to their place of origin.

The second characteristic of mudik Lebaran is in respect to the exodus before and after Lebaran home coming. The urban exodus during the last days of Ramadhan marks the Indonesian Lebaran as different from Lebaran celebrations elsewhere in Muslim Southeast Asia such as in Malaysia, Brunei, the southern Philipines and southern Thailand or even in the Middle Eastern Islamic countries. From year to year, tens of millions of Indonesians leave Jakarta and other urban centers to embark on journeys that may take them thousand kilometers away to their home towns or villages using all kinds of public transportations, private cars or even motorbikes. In 2010, as in previous years, Lebaran traffic recorded the busiest traffic of the year. The Ministry of Transportation ${ }^{3}$ reporting on the traffic during Lebaran season in year of 2010 estimated the following figures, per category as shown in the following chart:

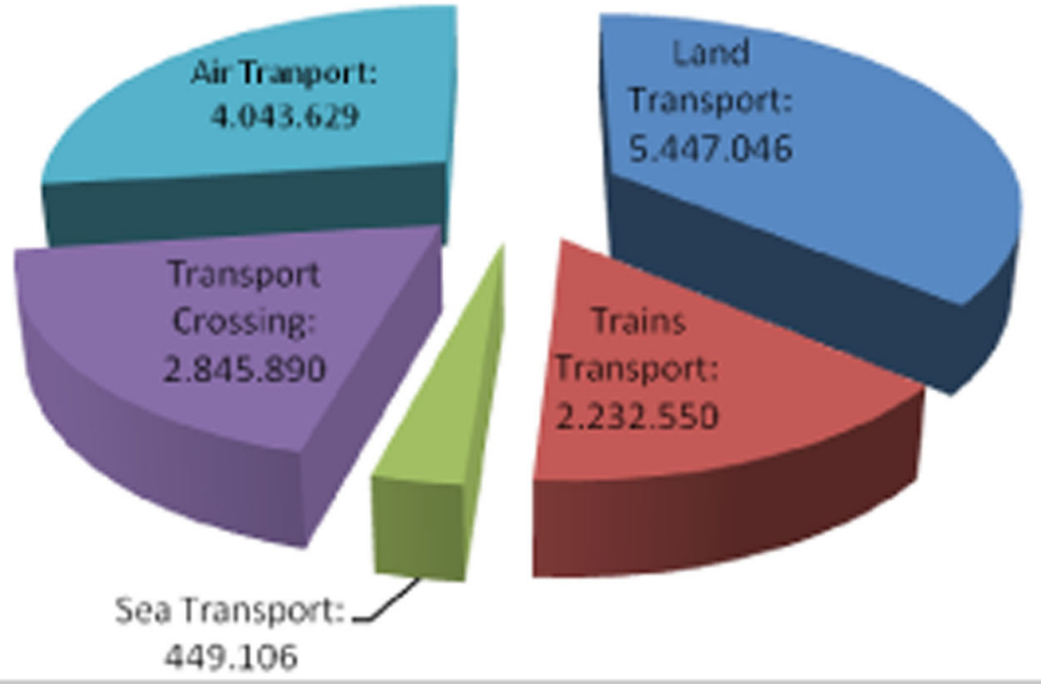

3 Online: http://www.dephub.go.id/lebaran/ (accessed January 2, 2011). 
The chart above clearly suggest the degree of street congestation that this mass exodus must necessarily create as thousands of travellers go to their home villages from cosmopolitan Jakarta on generally at the same time. Months prior to Lebaran bus or train tickets to various destinations are typically already sold out. All this constitutes a free flow of humanity, determined by private decisions and individuals movements regulated only by the supply of tickets, the availability of transport and the designation of public holiday days. The number of returnees, the moment of departure, and their destinations are not controlled and everbody focuses on their own intension to return to their home village of origin (kampung halaman).

In 2010 Lebaran fell on 10-11 September with a collective holiday (libur bersama) from September 9 to 13th. In Indonesia, this becomes the longest holiday of the year. During Lebaran holidays typically business in Jakarta and other urban centers shutdown or are greatly reduced, educational institutions and offices are closed, industrial activities stopped and the delivery of newsfeeds for the press are on hold. Everything stops as everybody including the non-Muslim minorities and Indonesians all around the world celebrate Lebaran: in a sense as a national get together, but in fact as celebration of family.

\section{Images of Mudik Lebaran, an interaction of tradition and cosmopolitanism}

If we are to properly understand this annual migratory behavior, it is of course important to keep in mind the modern images that have become associated with mudik Lebaran, such as the national public holiday, mass traffic, and the ritual of mass consumption that present giving generates. There is also the question of self representation as Indonesia, with a population of nearly 240 million people has the largest Muslim population in the world. There is also the increasing importance of electronic devices such as telephone and cell phones providing voicebased and message communications to help keep people in touch. 
However, despite the popularity of such technologies in Indonesia at large, the tradition of mudik Lebaran depends upon the need to go home in person: to ask for forgiveness from their relatives and friends and neighbors in a face to face situation remains obligatory. It is due to the belief that asking forgiveness to others could only be done by asking it in person (Sairin 2005:193). People go from door to door around the neighbourhood and shake hands in person (salam-salaman or bawal) with long-time neighbours who they may see only once a year. But most importantly, this 'forgiving tradition' is conducted within the family setting.

A special case of this tradition, unique to central Java is the sungkeman tradition which is usually held on the second day of the Lebaran. The word "sungkeman" is derived from "sungkem", meaning to show respect by bowing on one's hands and knees. ${ }^{4}$ Instead of shaking hands, people bow before their parents. It derives from the tradition associated with Javanese royalty, and this undoubtly is an influential source in establishing the 'forgiving tradition' as a popular tradition in Java. The family of Sunarto who still carry Solonese royal blood for example, held the sungkeman tradition on the second day of the Lebaran. When interviewed, he mentioned that for Javanese who still hold a Royal family ethos, tradisi sungkeman is still well maintained.

Coming home, however, is also a way of demonstrating success. Coming home in cars - driven by one's chauffeur for instance - or by plane or an executive train is an expression of success, prestige and demonstrably, of modernity. For lower classess of the society, the overcrowded bus or train is a choice of necessity. Typical of their experiences is the account of a 25 year old woman who recounted her agonising experience of waiting for eleven hours in Jakarta's Jatinegara train station queueing to get an economy fare train ticket home to Solo. When, finally, she got onboard, she got to sit for further fifteen hours in an overcrowded train to her village, Gemolong, four hundred and seventy seven kilometers 
away. Working as a household maid in Bekasi, a modern suburb of Jakarta where she earned Rp 500,000,- (US\$ 51) per month she was returning home to be with her two daughters left behind in the village and for whose future she was going to the city to work. In this case then the 'home coming tradition' was reversed-mother was returning to her children - since in this case economic imperative forced the parents to leave. To her-and people like her in a similar economic positionwhatever the rural village still represents, the city is the destination of hope.

Regardless of the economic circumstances, going home in present remains obligatory for the persons who have left, often expressed in extreme, even exaggerated form. As in the case of a motorbike traveller interviewed. In order to overcome the expensive cost of travelling, he chose a motorbike as his mode of transportation. He travelled the four hundred seventy seven kilometers to his home with plastic bags stuffed with food and clothes and other oleh-oleh (gifts) hung on the motorbike and a wooden board extended from the bike's seat to fit extra luggage. For this young man who works in Jakarta in a glue factory, it was his fifth Lebaran trip by motorbike. This time, however, he did not drive his own but borrowed one from his sobat (good friend). Implied though not directly admitted, the reason for this become clear when he mentioned that the Tiger (a Japanese branded motorbike) which he borrowed from his friend made him look more impressive.

I prefer driving motorbike. It is very inconvenient (sek-sekan) if I took bus or train. Motorbike is much more economical and of course practical. We also use it when we travel to visit our relatives in the village. We do not need to spend extra money for that. I went home alone so, it was no problem. I took a rest twice in Cirebon and Pekalongan and each took a nap for an hour or so. I drove Tiger so, it was really fun and makes me feel happy. 
Of equal importance for Mudik Lebaran is clothing. Clearly, it plays a key and immediate role as symbol of returnees' achievement of success and also in demonstrating the modernity achieved by leaving home. New clothing is worn, the use of electronic devices such as hand phone and Ipod are openly displayed in order to demonstrate peoples' familiarity with 'global modernity'. When used spontaneously in the home village it demonstrates the returnees' freedom from an identity attached to what was their former village home. In Indonesia 'village' is associated with informality, poverty, and the retentition of rural traditions in an urban setting (Rukmana, 2007) and places which are considered on the margin, backward and less developed. Thus while coming home to confirm the values of family and tradition, the returnees simultaneously are concerned to demonstrate their distance, their separation from the past, their display of modernity and their own capacity to break from tradition and bring about change into their lives.

The second dominant theme, which is closely intertwined with the display of clothing and gadgets is a shift of language. Language is important here because in the vast mix of ethnic, linguistic and regional difference that makes up contemporary Indonesia, language -or accent or word choice - is the easiest way to identify a person's region of origin. In this context, Indonesian language or Bahasa Indonesia represents cosmopolitanism and modernity, the language of trans-regional mobility. Javanese, in this context, becomes a regional language, tied to place, to immobility and tradition. In the 'status stakes' the most prestigious linguistic signs are those linked to the dialect of Jakarta commonly referred as bahasa gaul. ${ }^{5}$ This is illustrated in an interesting case of a young couple who proudly informed me that they have a five year old son who still retains his Jakarta dialect. They had migrated to Jakarta to make a living until after several years of experiencing desperately a hard life as a city-bound commuter in Bekasi, the periphery of Jakarta, the mother had finally decided to return home to her village. From

$5 \quad$ For more information of a discussion on Bahasa Gaul see: Hanan, David: pp 54-69. Changing Social Formation in Indonesian and Thai teen Movies in Ariel Heryanto (ed); Popular Culture in Indonesia, Fluid Identities in Post-Authoritarian Politics, London\&New York, Routledge, 2008. 
my informal interview (ngobrol-ngobrol) with this woman it became obvious that she was upset about the way her son was mixing 'village' Javanese in his speech, showing signs that he was gradually adopting Javanese speech and loosing his Jakarta 'advantage'.

Hhhh, (sigh) we live in the village now. Our languange becomes mixed. It is sad. My son said 'Moh-moh' instead of 'enggak mau' (I do not want it). What is that? His Indonesian language turns to be not cool any more heheheh...(laughing).

(Siti, Interview, September 2010)

Siti's case reveals that in rural Middle Java, uttering Indonesian language is an expression of modernity although for some it is a matter of practical necessity as well. From this perspective, speaking Indonesian language instead of Javanese is one expression of becoming modern in Middle Java. This observation applies equally to radio and television in Surakarta and Yogyakarta; as operators from the representative technologies of modernity, announcers try their very best to speak like Jakartans in order not to be considered ndeso (people from village who are backward). This suggests that although mudik Lebaran demonstrates that in Java urban and rural life remain inseparable, there nevertheless, exists a distinct 'fault-line' dividing contemporary Indonesian society. Being able to demonstrate an association with the center of Indonesian modernity — by speaking with Jakarta's accent—or being Jakartanised in terms of behavior and dress is to demonstrate pride in symbols of modernity, and by implication, distance from a rural unmodernised past.

\section{The Political Meanings of Mudik Lebaran}

Besides functioning as the opportunity for families to reunite, for successful and less successful rural migrant to 'show off', there at least are three more 'practical' public functions served by mudik Lebaran. Most immediately it serves to underpin the psychological and physical 
hardship that Indonesia's modern economy has imposed on a national that statistically remains predominantly rural. Shirley Christie (2010) has reported that where more than 30 percent of Indonesia's population is between 19 and 24 years old, the youth unemployment averages between seven and eight percent. As a consequence, work migration has become an increasingly significant phenomenon both in its intensity and diversity over recent decades (Morawska, 2001; Okólski, in Wallace and Stola, 2002, p. 105). Jakarta, which offers such an array of possible kinds of formal and informal jobs catering for all levels of aspiration and skill, for Indonesians anywhere of the archipelago and whatever their social class position, becomes a perfect destination for those unemployed young villagers. On the other hand, Lebaran home comers open the way to their relatives who are jobless in the village. The extend to them, the lure of the malls, the taste of culinaries, the promise of work and income and the pleasure of modern recreation. They hold out to their village relatives the promise of different life style not simply the material gleam of economic gain (Warouw 2008:105; Hadiz 1997:124).

For a young gentleman I spoke with in the village of Tegaldowo, the 'urban' represents modernity which becomes both an aspiration and a future (Warouw:2008), by extension modernity.

It is better for me to go to Jakarta. I do not want to work (macul) in the padi field (sawah)...No good income. It actually will make my skin black. I would accept any kind of job there. First of all I will help my Aunt in the market (pasar). Later, I will see what I could do next. But to stay in the village and work in the padi field is my last choice.

(Interview statement, September, 2010).

Eventhough the core functions of Mudik is asking forgiveness and to enable family gathering or Silaturohim as Fauzi, Ridwan (2010) states, Lebaran is also the perfect time for unjuk gigi, that is an opportunity to show off. In his view, returnees feel that they have a 'social responsibily' 
to show their new found wealth as a means of demonstrating their success story by the display of clothing and possessions and looking good. One interviewee, a 57 year old man proudly informed me that his three children drove their own automobile for their Lebaran home coming. It is not difficult to see owning a car(s) becomes a contemporary symbol of wealth and serves to bolster social prestige particularly in Indonesian countrysides. It reflects urban life style and the owner's success story, and as anywhere else in the world, social status is confirmed, if not determined by material ownership. Some returnees admitted that using rented automobile for Mudik Lebaran has become a common practice to achieve this recognition. Automobile ownership and even a superior brand of motorbike can significantly increase someone's social status in the village where this is ussually measured by material possession.

Consumptive behaviour is also clearly seen during this home coming moment. Some informants revealed that Lebaran is the most extravagant period of the year. In this connection one telling example is an informant, who earns only Rp 1,000,000,-(US\$90) monthly mentioned that she had spent two million Rupiah (US\$220) on clothes and gifts for her family in the village. She admitted that Lebaran is one month of the year when she spends most money. This suggests that for many managing social cost of an ideal mudik Lebaran represents an impossible goal. However, this informant looked happy enough to be able to achieve the amount she did and this seems to confirm Wolf's findings in relation to rural Javanese factory daughters, who saw their work as a way of increasing their 'buying power' so they could conform to 'modern style' (Wolf 1992:193).

The third meaning of mudik is as a touristic moment. After having been buried under the weight of routine jobs, the Lebaran home coming takes on momentum of tourism for those whose ancestors are from villages. It may provide a reminder of their past, the nostalgia of a much slower, carefree and happy rural life. Moel, a father of two children for example, told me how tired he was from the industrial, capitalist disciplines and the general hardship and pressure of work in Jakarta 
resulting from the very bad air pollution, every day traffic jam and the high living cost. Warouw (2008) study of women factory workers in Tangerang, a foremost manufacturing center close to Jakarta, describes the high level of stress experienced by such urban workers who has established a relatively permanent urban existence far away from their rural hinterland, as a feeling of being 'chased' (keteteran). Using Warouw's word, the practice of mudik Lebaran could be a strategy for those 'urbanised' people with which to manage their 'alianation' in the urban center. Romanticising the thought of it, maintaining close connection to their village of origin provides the opportunity to feel emotionally secure. In his study, those urban migrant workers imagine the countryside - their place of origin — as a place of natural purity; of rice fields (sawah); clean rivers and peace of mind (Warouw 2008:108109). He has further noted that the practice of Mudik or returning to one's place of origin helps keep the idea of rural nature and peaceful life, despite the fact that in the countryside itself rural development has dismished people's experience of nature and replaced it with urbancentered themes of modernization (Warouw 2008:109).

Returning home however, does involve a degree of adjustment. I observed, at the very beginning of their stay in the village, they usually grumble about food and the lack of the facilities they were used to in the cities such as air conditioner and modern entertainment. They also prefered to speak Bahasa Indonesia rather than to have to revert to the intrancies of Javanese. "How could my son ask for chicken nugget here as if we were in Jakarta? I gave him chicken's heart (iwak ati)", a 37 years old mother told me in her Javanese language. But after sometime, homecomers begin to enjoy the social integration and the genuine family life in the village. Here they gain a degree of social respect which they rarely found in cities and as reintegrated into village society gradually reverted to speaking in which this respect was given and received. 


\section{Conclusion}

From the findings I have presented, I would argue that Lebaran home comers' experiences of the present 'different world', their present urban life, with its different frames of meanings does not significantly suppress their longing for and engagement with their former village's frames of meanings. The Jakarta returnees who originate from the village of Tegaldowo and Gandurejo where most of my fieldwork was conducted experience this type of 'simultaneity' in their lives. Although they are embedded in the social lives in their current 'home' in the city, they are still intimately connected through the practice of this regular mudik. In this regard, the pratice of mudik Lebaran inverts the common understanding that the line between urban and rural is delineated independently. As I have observed, they do not have that feeling of displacement which strips away those migrants' rural identity, or to use Lowenthal's word, their past. In this regard, they could even negotiate double or multiple identities. These issues became important for their sense of who they are. During their short visit in the village, they place themselves again as members of the village community by participating in village festival (s) such as Bakdo Ketupat or Bakdo Sawal, a Javanese tradition held one week after Lebaran. This social and cultural practices what Michael Leaf terms the 'interaction zone' where urban and rural activities are juxtaposed (cited in Riwanto Tirtosudarmo, 2008:163).

The picture of mudik Lebaran sketched above suggests that urbanrural affinity is well managed. The cultural tradition of Mudik Lebaran provides returnees a regular contact with their 'mother village' (Burghoorn 1981:67), their rural identity and to the place where they continue to belong to. Referring to Lowenthal's idea of the relationship between the past and present where the past has been the source of familiarity, guidance, identity, enrichment and escape (1985), mudik Lebaran becomes a pivotal lens which captures both the way urban migrants zoom back and forth between their past and present 'country' in order to manage an intimate interaction between their rural and urban life at the same time. Swazey (2008), writing on Indonesian immigrant 
population in the Seacoast region of Southern New Hampshire, suggests that those Indonesian 'transnational migrants' or 'transmigrants' also live within two systems and that transnational experiences facilitate a reconnection with aspects of home from a far. Although they are embedded in institutional, political and social life in their 'current home' in the United States, they are still intimately connected through kinship and other social relationships to Indonesia. In the context of regional level, a concept of 'lived simultaneity' by Glick Schiller (2005) (cited in Swazey 2008:61) is aptly helpful to see this Mudik Lebaran phenomenon. Schiller further explains that it is urgent that we understand that it is possible to become incorporated with a locality, its economy, its institutions, and its forms of cultural production and at the same time live within social networks that are intimately tied elsewhere. ${ }^{6}$ Within this regard, the "new or the present or the urban 'home' does not strip their past or 'rural' life away.

This study shows how urbanised Lebaran returnees are in fact living simultaneously within two cultural and social systems. For them, their village lives - their 'past' - are not then a bygone age. It continues to be associated with the present or (urban). As Lowental put it (1985:224) they want to make the past present and to make the distant near. The paper finally suggests that the continues interplay between village and town prove that neither past/present nor rural/urban are in categorically opposed realms (in different "countries").

\section{Bibliography}

Boulanger, Clare L. (2002) 'Inventing Tradition, Inventing Modernity: Dayak Identity in Urban Sarawak', Asian Ethnicity, 3:2, 221-231. Downloaded on October $11,2010$.

Burghoorn-Lundstrom, Wil. (1981) 'Minahasa Civilisation' Gothenburg Studies in Social Anthropology, Goteberg: Acta Universitas Gothoburgensis.

$6 \quad$ Schiller, Nina Glick, Lived Simultaneity and Discourses of Diasporic Difference. "Displacements and Diasporas (2005) in Swazey, Kelly (2008); Carrying Culture and re(creating) Nation Through Christianity: Minahasan Culture nd Identity in Transnational Indonesia Churches in New England, Master Thesis, University of Hawai'i, Manoa. 
Deden, Rukmana. (2007), http://indonesiaurbanstudies.blogspot.com/2007/03/ urbanization-and-suburbanization-in.html

Dieleman, Marleen. (2011), New Town Development in Indonesia: Renegotiating, Shaping and Changing Institutions, Bijdragen tot de Taal-, Land-en Volkenkunde, Vol.167, no.1 (2011). Pp 60-85. Accessed online, downloaded on March 2011.

Fauzi, Malik Ridwan. (2010), Fenomena Mudik Lebaran; Suatu Kajian Sosiologi Ekonomi in Celoteh Sosial Budaya; http://www.celotehmalik.co.cc/2010/09/ fenomena-mudik-lebaran-suatu-kajian.html, downloaded on October 16, 2010.

Guiness, Patrick. (2009) 'Kampung, Islam and the State in Urban Java' Asian Association of Australia in association with NUS Press, Singapore.

Hanan, David. (2007) Changing Social Formations in Indonesian and Thai teen Movies in Heryanto, Ariel (ed) (2007), Popular Culture in Indonesia: Fluid Identity in Authoritarian Politics, Routledge, London and NewYork. P.

Jackson, Anthony Von. (1987) Anthropology at Home: ASA Monograph 25, Tavistock Publications in association with Methuen Inc, New York.

Hadiz, V. (1997) Workers and the State in New Order Indonesia, London, Routledge.

Lu Y. (2010), Rural-Urban Migration and Health: Evidence from Longitudinal data in Indonesia, Columbia University, New York. Accessed on line, http://www. ncbi.nlm.nih.gov/pubmed/19897297, downloaded on November 12, 2010.

Lowenthal, David. (1985) 'The Past is a Foreign Country', Cambridge, Cambridge University Press.

Rukmana, Deden. (2007) Urbanization and Suburbanization in Jakarta, Indonesia's Urban Studies, Accessed online: http://indonesiaurbanstudies.blogspot. com/2007/03/urbanization-and-suburbanization-in.html, downloaded on November 1, 2010.

Saswik, et.al. (2010) Thematic Articles: The Challenges of Migrant's Social Integration; Identity over Commitment, Work Environment and Health Outcome among Immigrant workers, Journal of Identity and Migration Studies, Vol.4 No.2, 2010.

Schiller, Nina Glick. (2005) Lived Simultaneity and Discourses of Diasporic Difference in Anderson, W. Wanni and Robert G. Lee (eds) "Displacements and Diasporas: Asian in the Americans, New Jersey Rutgers University Press. P.159-169.

Syahyuti, 2008 (http://syahyuti.multiply.com/journal/item/6/6) downloaded on Nov 2, 2010.

Shierly, Christie. (2010) High Rate of Youth Umemployment Presents Big Challenge; World Bank, The Jakarta Globe. Accesses Online: http://www.thejakartaglobe. com/bisindonesia/high-rate-of-youth-unemployment-presents-big-challengeworld-bank/431663, downloaded on December 2010.

Sairin, Sjafri. (2010) Riak-Riak Pembangunan; Perspektif Antropology, Yogyakarta, Media Wacana. p.191-203. 
Swazey, Kelly. (2008) Carrying Culture and re(creating) Nation Through Christianity: Minahasan Culture and Identity in Transnational Indonesia Churches in New England. (Master Thesis, University of Hawai'i, Manoa.)

Tirtosudarmo, Riwanto. (2010) Social Transformation in the Northen Coastal Cities of Java: A Comparative Study in Cirebon and Gresik, Journal of Indonesian Sciences and Humanities, Vol. 3, 2010, pp. 161-170 URL: http://www.kitlvjournals.nl/index.php/jissh/index, downloaded on January 17, 2010.

Wallace, Clare and Stola, Dariusz (eds). (2001) Patterns of Migration in Central Europa, Basingstoke \&New York, Palgrave.

Warouw, Nicolas.(2008) Industrial Workers in Transition; Women's Experiences of Factory Work in Tangerang in Ford, Michele and Parker, Lyn (2010) Women and Work in Indonesia, USA and Canada, Routledge, pp.104-119. 